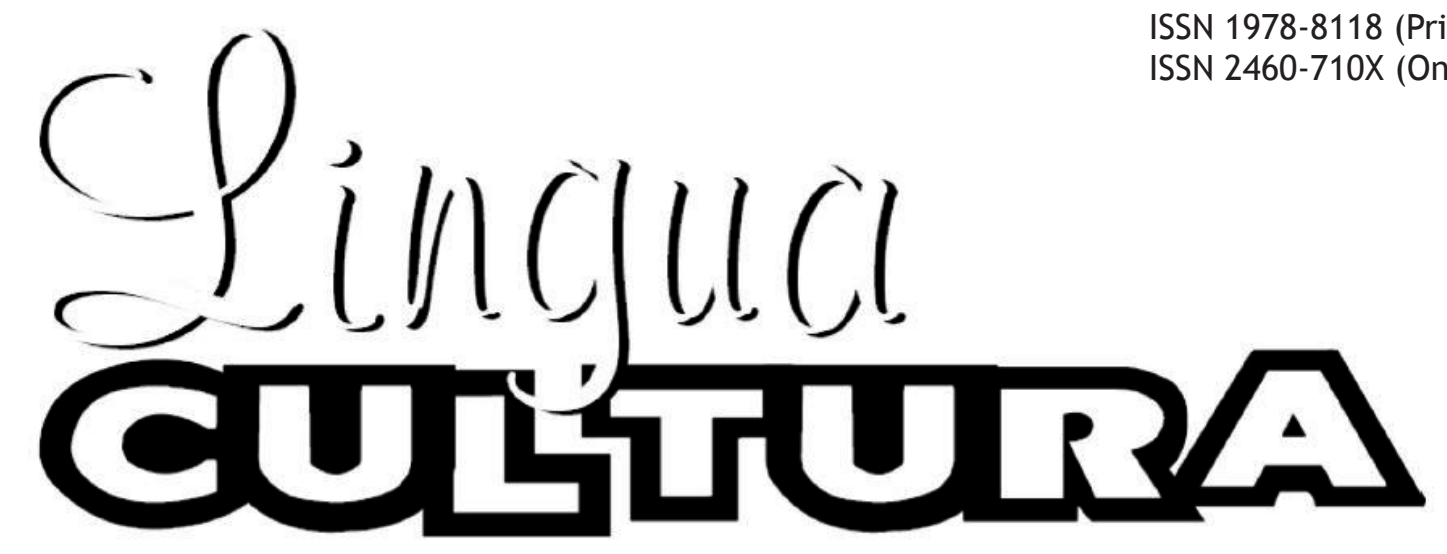

Vol. 9 No.2 November 2015

Ketua Dewan Redaksi

Dewan Redaksi

Redaktur Pelaksana

Editor Bahasa dan Setter

Sekretariat lenneke Indra Dewi

Endang Ernawati
Akun
Sri Haryanti
Rosita Ningrum
Indiwan Seto Wahyu Wibowo

(Universitas Bina Nusantara) (Universitas Bina Nusantara) (Universitas Bina Nusantara) (Universitas Bina Nusantara) (Universitas Multimedia Nusantara)

Arta Moro Sundjaja

Noerlina

I. Didimus Manulang

Dina Nurfitria

Karen Phang

Holil

Atmawati

Haryo Sutanto

Eka Yanti Pangputri

\title{
Description
}

Lingua Cultura is a semiannual journal, published in May and November, first publication is in 2007. The journal contents are managed by the English Department, Japanese Department, and Chinese Department, Faculty of Humanities, Bina Nusantara University, Jakarta, Indonesia. The objective of the journal is to provide a forum for lecturers, researchers, students, and practitioners to present their ideas, concepts, and new theories in language and culture; and to disseminate theory, research, and teaching reviews to the academic community of language and literature studies in Indonesia and abroad. Lingua Cultura presents articles based on research in the study of language, culture, and literature. The coverage of language includes linguistics and language teaching, the area of culture includes cultural studies and social studies, and the coverage of literature covers the analysis of novel, film, drama using the relevant theories and concepts. Lingua Cultura has been indexed by Google Scholar, Indonesian Publication Index (IPI), the World Catalogue (WorldCat), Bielefeld Academic Search Engine (BASE), Academic Resource Index (ResearchBib) and Scientific Indexing Services (SIS).

Editor and Administration address

Phone

e-Mail

Homepage
: Research and Technology Transfer Office

Universitas Bina Nusantara

Jl. Kebon Jeruk Raya No.27, Kebon Jeruk, Jakarta Barat 11530

: 021-5350660 ext. 1708

: hsutanto@binus.edu

: http://journal.binus.ac.id/index.php/lingua

http://research.binus.ac.id/journal/lingua-cultura 


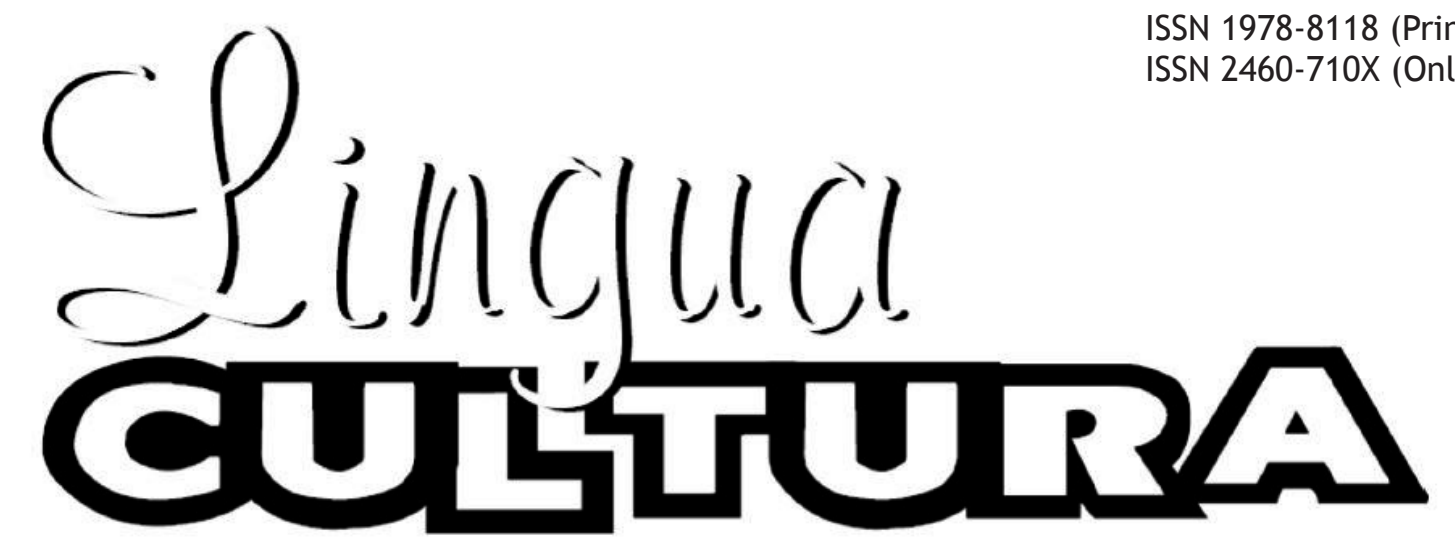

Vol. 9 No.2 November 2015

\section{DAFTAR ISI}

\section{Paramita Ayuningtyas}

Deconstructing the Stereotypes of Women through a Female Voice in Burial Rites (2013)

by Hannah Kent.

Soraya

The Subaltern Voice in A Thousand Splendid Suns by Khaled Khosseini......

\section{Dian Natashia}

Konsep Cantik pada Iklan Cetak Majalah Kartini Tahun 2014

dan Koran Kompas Tahun 1979: Suatu Analisis Semiotik

(Beautiful Concept on Printed Advertisement of Kartini Magazine in 2014

and Kompas Newspaper in 1979: A Semiotic Analysis)

Timur Sri Astami

Model Pembelajaran Kaiwa Tingkat Dasar sesuai dengan JF Standard

(Learning Model of Kaiwa Basic Level based on JF Standard).

lis Muhayaroh

Fenomena Ikumen sebagai Salah Satu Perubahan Peran dan Identitas Ayah

dalam Masyarakat Jepang Modern

(Ikumen Phenomenon as One of Father's Role and Identity Changes in the Modern Japanese Society)

Siti Nurani; Amrina Rosyada

Improving English Pronunciation of Adult ESL Learners through Reading Aloud Assessments

\section{Nandy Intan Kurnia}

Motherhood in the American Woman Poet's Perspective:

A Short Glance at Allen's Rock Me to Sleep.

\section{Andriani Sinarsih; Yuvina Handani; Cendrawaty Tjong}

Dampak Psikologis Tokoh Pria dan Wanita dalam Film Tangshan Da Dizhen

(Psychological impact on Men and Women Characters in Film Tangshan Da Dizhen).

Widya; Dewi Mutiara Indah Ayu

Translation of Passive Voice Found in the Novel The Sea of Monster

By Rick Riordan and its Translation By Nuraini Mastura.

Paramita Kusumawardhani

Error Analysis in Writing an English Narrative Composition. 